the radioactive isotopes of widely differing elements. Actual experience with this instrument has shown that both modes of operation are possible and successful; they provide alternative experimental approaches to the particular problems, and Dr. Bernas discussed their relative merits. $\mathrm{He}$ also described in some detail the work on technetium. which is prepared by cyclotron irradiation of $a$ molybdenum target and thon mass-separated. An interesting example of the application of the separator to alpha-particle spectroscopy was also described.

A lively discussion followed every paper, and it was felt that the conference had had some important results in directing attention to a great variety of applications of mass spectroscopy, and in describing many applications of electromagnetically enriched isotopes. Hitherto, the more spectacular application of radioisotopes and the relative ease of their techniques of use has overshadowed the uses of stablo isotopes. It was felt that the present conference would show the rich field of work still waiting to be done in the latter field. In summing up, one might say that three main types of activity could be clearly recognized at the conference : the work of the two groups at Oak Ridge and Harwell in the provision of enriched isotopes for basic research of all kinds; the work of several European groups in the application of medium-sized isotope mass-separators to the direct study of a great range of nuclear problems; and lastly the large numbers of research workers who essentially are applying the enriched isotopes provided by Oak Ridge and Harwell to a great variety of researches. An important result of the conference was that the common interests of these groups were clearly recognized and great stimulus given to their work. It is hoped that on publication of the proceedings a much fuller appreciation of this new field will be generally gained. The proceedings, including lectures, discussion and illustrations, will be published shortly by Butterworths Scientific Publications, Ltd., London.
M. L. Smirr

\title{
MANAGEMENT AND HUMAN RELATIONS
}

\begin{abstract}
$\mathrm{A}^{-1}$ $\mathrm{N}$ attendance of nine hundred members at the annual conference of the Institute of Personnel Management at Harrogate during October 7-9 is an indication of the growing importance attached to the personnel function of management in British industry. Those attending came from very large and small manufacturing firms, departmental stores, nationalized industries, publie corporations, insurance and other commercial concerns, educational institutions and the Armed Forces. A number came from overseas. At the plenary sessions speeches of a high order were given, and at the various sectional meetings the investigations now being made into the behaviour of people in industry by a number of research organizations woro discussed.

Sir John Hunt, leader of the British Mount Everest Expedition in 1953, opened the conference with a challenging paper on the needs of youth in a Welfare State. There are, he said, many signs that the spirit of young people is either flagging or misdirected; there is too much apathy and hooliganism abroad. A great deal of fine work is still being done to help young people find their feet and set them on the road to good citizenship, and yet it would be foolish to be complacent and suppose that more could not and should not be done. Something is lacking in the opportunities offered, in the guidance given: What is this lack? First, the incentive to achievement is generally inadequate. If it is accepted that one of the needs in every individual is a sense of purpose, then the opportunity of achievement is an essential step in providing that purpose. Secondly, there is a great need for leaders, both in numbers and in quality. The paid official alone will not do, and the need is for more volunteers, because they bring to young people a variety of experience of contemporary life. Ideally, leaders should have graduated from a similar background to members of the group - the best leadership is leadership from within the group, not from above it. The main source of youth leaders should be ex-members of the organizations themselves rather than older men implanted from outside and from a different environment.
\end{abstract}

A scheme should be devised which embodies incentives and sets certain targets or standards of achievement. How can such a scheme be made attractive and how can it work ? Can a scheme of wide application be devised which might draw in more young people? Sir John suggested that it should be planned under four headings : the development of a hobby-a technical, scientific or artistic skill ; the development of physical fitness-this calls for moral as well as physical stamina; outings, whether on foot or cycle or in a small boat-these are of tremendous value to the character training of young people and can be extended progressively until they assume the character of expeditions; and the instilling of the spirit of service-this is best caught by example, and the example must come from the leader.

Sir John was followed by Sir Richard Coppock, general secretary of the National Federation of Building Trade Operatives, who said that, in the main, the weakness of the building industry is on the managerial plane. $\mathrm{H}_{\theta}$ was particularly concerned about the missed opportunities for consultation between management and worker. The experience the workers possess is the basis of Britain's prosperity and is unequalled in any board-room in the country. Things do not go wrong on the drawingboard, he maintained, but when machines are being run and built, and he quoted the Comet aircraft as a good example of this. Half the difficulties in his industry arise because the employer does not enlist the goodwill of his men by telling them all the facts. The great problem facing management is how to handle men. One of the most vicious things they can do, when an unofficial strike takes place over some potty tyranny, is to say: "You must all go back at once. We cannot see you". This, said Sir Richard, puts the trade-union official in a most humiliating position-he is humiliated before negotiations have even begun.

Some management problems in the British Broadcasting Corporation were discussed by the directorgeneral, Sir Ian Jacob. The Corporation employs 
13,823 men and women, made up of 3,230 monthly paid staff, 3,950 secretarial and clerical staff and 3,643 manual staff. They belong to some fifty nationalities and more than a hundred professions which, with the wide geographical spread, create peculiar problems. The executive management is carried out by a board which consists of the directorgeneral and six other directors. The directors of Sound Broadcasting, Television and External Services have purely functional duties, that is, they are responsible for a field of output and for the staff directly concerned with that output. The director of administration and the director of technical services have responsibilities which permeate the whole Corporation, though each has a considerable direct area of responsibility in addition. 'The sixth director is the chief staff officer to the directorgeneral on policy matters.

The Corporation has no eriterion of profit by which to test the success of the methods employed by its various parts, and it must therefore endeavour to regulate administration by giving to directorates the guidance emanating from specialist departments that are centrally established. One of these is the Central Establishment Office, which continuously investigates, in close co-operation with the heads of the departments concerned, staffing, organization and methods. Between two and three hundred technical assistants are recruited for the engineering staff each year, while for the programme and administrative staff a small number of young men and women are recruited straight from school or from university, though the majority enter at a later stage. The main need with regard to staff is for people who have attained a certain degree of experience and skill in the world and who enter the Corporation in response to public advertisement.

In such a diverse and dispersed body as the Corporation, a system is necessary which enables people to move essily from one compartment to another, for otherwise promotions would tend to remain within departments and a general rigidity would ensue. This problem is solved by a promotion system affecting the whole organization, a flexible grading system, and a scheme of bonuses for outstanding work and creative skill. Such a large organization gives rise to considerable problems of communication, but these are minimized by regular meetings up and down the chain of command and staff representation. Considerable staffing difficulties have been caused by the formation of the Independent Television Authority, and drastic measures have been used to deal with them. With the ending of the Corporation's solitary position in the country, broadcasting, and television in particular, are now moving into a new phase in Great Britain.

The development of research into the human factor in industry was outlined by Mr. A. B. Waring, chairman of Joseph Lucas (Industries), Ltd. This had, in 1953, led to the setting up of the Joint Committee on Human Relations in Industry, with himself as chairman, to advise the Department of Scientific and Industrial Research and the Medical Research Council on research in this field. The majority of the projects it has accepted fall under four broad headings: incentive schemes with reference to the social factors associated with them; technological change with reference to the human implications involved; management organization with reference to staff supervision and functional specialists; promotion and training. There are also special projects such as relations between office staffs and factory workers and the effects of ageing on adaptability to work.

It is possible, he said, to approach the subject of human relations in industry from a basic theory that any community left to its own devices will establish for itself in the course of time a modus vivendi which will satisfy the majority of its members so that the pattern of relationships among them and their general contentment will remain more-or-less constant. But when violent changes are imposed by wars, the impact of other civilizations or the upheavals due to the changes that industrialization brings about, the pattern of society becomes distorted and discord ensues. Changes in the pattern of work and employment brought about by changes in the circumstances of trade and by ever-increasing mechanization can result in disturbances ranging from súppressed resentment to open resistance. Man, being a reasoning animal, is prepared to accept change when it is properly presented and when he is satisfied that he will benefit or that his future depends on it.

'The best human relations will exist in those factories in which leadership qualities are high and well founded and are regarded as being no less important than technical and administrative ability, and where both leaders and led work in circumstances that maintain continuously both their status and their morale. Mr. Waring suggested that before any project of research into human relations in industry is undertaken, it should first pass the test of whether or not it falls into the category of a deeply rooted problem of general significance; if not, and if it can be classified as a problem resulting from inadequate local management, it is unlikely to be a subject for basic research and may well be dealt with through management training and reorganization or through investigation by industrial consultants. But where, in a branch of industry, there is a general malaise evidenced by labour unrest with no apparent sensible justification, or where in specific instances the support of workpeople is withheld or there is either open or suppressed resistance the reasons for which are obscure, research is the obvious and perhaps most valuable method of approach.

Mr. Waring stressed the importance of choosing subjects for research in human relations most carefully; otherwise there is the danger of regarding such research as a type of industrial patent medicine. It is equally important that its practitioners should be worthy of their tasks.

T. H. HAWKINS

\section{OBITUARIES}

\section{Sir Malcolm Watson}

Sir Malcolm Watson, director during 1933-42 of the Ross Institute of Tropical Hygiene (London School of Hygiene and Tropical Medicine), died on December 28 at the age of eighty-two.

The successive steps which led to modern conceptions of the epidemiology of malaria were: (1) Manson's hypothesis that mosquitoes transmit the disease ; (2) Ross's confirmation that mosquitoes do transmit, and his own, most important, contribution showing that not all of them do so-- not the grey mosquito, not the brindled mosquito, only the dapple-winged one ; (3) Grassi's entomological addition that the mosquitoes which transmit malaria 